\title{
Enhancement of Nutrient Availability in Soil using Microbial Cultures in Soybean Grown on Vertisol
}

\author{
B. Kranthi Kumar*, Syed Ismail, K. Manasa and Anuradha Pawar \\ Department of Soil Science and Agricultural Chemistry, \\ Vasantrao Naik Marathwada Krishi Vidyapeeth, Parbhani 431 402, Maharashtra \\ *Corresponding author:
}

\section{A B S T R A C T}

\section{Keywords}

Chemical properties, Nutrient availability,

Microbial

inoculants, Soybean

Article Info

Accepted:

26 April 2017

Available Online:

10 May 2017
Field experiment was conducted during summer season of 2014-15 on Research farm, Department of Soil Science and Agricultural Chemistry, Vasantrao Naik Marathwada Krishi Vidyapeeth, Parbhani to enhance the nutrient availability in soil using different microbial isolates by using soybean as a test crop. The results emerged out indicated that significant increase in nutrient availability in soil after harvest of crop was more in the plots treated with RDF along with inoculation of Rhizobium + Trichodermaviride. The chemical properties of soil such as soil $\mathrm{pH}$ were found to be decreased due to inoculation of microbial isolates whereas, electrical conductivity was found to be increased. Moreover, organic carbon was found to be increased and calcium carbonate content was decreased.

\section{Introduction}

Soybean (Glycine max (L.) Merrill) is generally referred to as golden as well as wonder bean because seeds are rich in oil $(20 \%)$ and proteins (40-44\%), amino acids, lysine $(5 \%)$, which is deficient in most of the cereals. In Maharashtra state, soybean crop is grown on an area of 38.08 lakh hectare with total production 30.72 lakh MT with average productivity of $808 \mathrm{~kg} / \mathrm{ha}$ (Anonymous, 2014). The poor productivity of soybean is mainly due to imbalanced application of nutrients and use of traditional varieties. Under such situations, use of Rhizobium and phosphate solubilizing bacteria (PSB) had shown advantage in enhancing soybean productivity. Microbial inoculants are cost effective, eco-friendly, and renewable sources of plant nutrients. Rhizobium and PSB assume a great importance on account of their vital role in $\mathrm{N}_{2}$-fixation and P-solubilisation, the introduction of efficient strains of $\mathrm{P}$ solubilizing species such as Bacillus megaterium, Biovar phosphaticum, Bacillus polymyxa, Pseudomonas striata, Aspergillus awamori and Penicillium digitatum in the rhizosphere of crops and soils has been reported to help in increasing phosphorus availability in the soil. Macro-nutrients such as nitrogen, phosphorus and potassium play a crucial role in plant growth and yield. Soybean nitrogen requirements are met in a complex manner, as this crop is capable of utilizing both soil $\mathrm{N}$ (mostly in the form of nitrate) and atmospheric $\mathrm{N}$ (through symbiotic 
nitrogen fixation). Some researchers suggested that $\mathrm{N}$ fertilization is not necessary for inoculated soybean. Whereas, others indicated that $\mathrm{N}$ fertilization is necessary to improve yield and quality of soybean depending on application rate. Bodkhe et al., (2014) reported that application of a small amount of $\mathrm{N}$ at planting called as "starter $\mathrm{N}$ " reported to beneficial to improve early growth and yield of soybean in most cases. A number of microorganisms are considered as challenging agents for agriculture to promote better nutrient uptake and availability for plant use particularly zinc mobilizing and acidifying cultures may help to increase the zinc and other micronutrients availability for the crops like soybean. Since the information on soybean to inoculation with Rhizobium and phosphate solubilizing bacterial inoculants is meagre. Summer soybean has a tremendous potential to be used as seed for kharif season. Keeping these points in consideration, field trial was conducted to enhance the chemical properties and nutrient availability in soil using microbial cultures in soybean grown on Vertisol.

\section{Materials and Methods}

The present investigation was carried at Research Farm, Department of Soil Science and Agricultural Chemistry, Vasantrao Naik Marathwada Krishi Vidyapeeth, Parbhani on Vertisol during 2014-15. The initial soil $\mathrm{pH}$ was 7.96, EC- $0.28 \mathrm{dSm}^{-1}$, organic carbon$5.26 \mathrm{~g} \mathrm{~kg}^{-1}, \mathrm{CaCO}_{3}-37.0 \mathrm{~g} \mathrm{~kg}^{-1}$ available $\mathrm{N}$ $190 \mathrm{~kg} \mathrm{ha}^{-1}, \mathrm{P}_{2} \mathrm{O}_{5}-16.7 \mathrm{~kg} \mathrm{ha}^{-1}, \mathrm{~K}_{2} \mathrm{O}-580 \mathrm{~kg}$

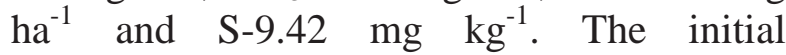
micronutrient status were available $\mathrm{Cu} 2.27$ $\mathrm{mg} \mathrm{kg}{ }^{-1}, \mathrm{Mn} 7.22 \mathrm{mg} \mathrm{kg}^{-1}$, zinc $0.56 \mathrm{mg} \mathrm{kg}^{-1}$, iron $5.28 \mathrm{mg} \mathrm{kg}^{-1}$. The soil was clayey in texture, low in organic carbon, available nitrogen, medium in phosphorus, sufficient in potassium and low in sulphur. As among the micronutrient status $\mathrm{Cu}, \mathrm{Fe}$ and $\mathrm{Mn}$ were above the critical limits but Available $\mathrm{Zn}$ content in experimental soil was found to be deficient. The treatments comprising inoculation with liquid inoculants of Bradyrhizobium and Bacillus megaterium (PSB) for soybean, used in alone and in combinations. Total eight treatments of bioinoculants were replicated three times in RBD. The experiment consists of 8 treatments of laboratory tested $\mathrm{P}$ and $\mathrm{Zn}$ solubilizers $\mathrm{T}_{1}$ $\mathrm{RDF}+$ Rhizobium; $\mathrm{T}_{2} \mathrm{RDF}+$ Rhizobium + Burkholderia cepacia; $\mathrm{T}_{3} \mathrm{RDF}+$ Rhizobium + Burkholderia cenocepacia; $\mathrm{T}_{4}$ RDF + Rhizobium +Pseudomonas fluorescens; $\mathrm{T}_{5}$ $\mathrm{RDF}+$ Rhizobium + Pseudomonas striata; $\mathrm{T}_{6}$ $\mathrm{RDF}+$ Rhizobium + Trichoderma viride $; \mathrm{T}_{7}$ $\mathrm{RDF}+$ Rhizobium + Trichoderma harzianum; $\mathrm{T}_{8} \mathrm{RDF}+$ Rhizobium + Bacillus megaterium . Seed treatment was done before sowing with liquid bioinoculants each @ $50 \mathrm{ml} 10 \mathrm{~kg}^{-1}$ seed. The crop was raised following recommended agronomic practices. The recommended dose of chemical fertilizers was applied@30:60:30 NPK kg ha ${ }^{-1}$ at the time of sowing. Intercultural operations like thinning, weeding, spraying of insecticides, fertilizer application and schedule of irrigation for soybean crop was carefully followed. The crop variety used was MAUS162. The soil samples were collected after harvest of soybean for analysis of chemical properties and available nutrient status as per standard procedures.

\section{Results and Discussion}

\section{Chemical properties of soil}

The result presented in Table 1 indicated that change in soil $\mathrm{pH}, \mathrm{EC}$ and $\mathrm{CaCO}_{3}$ after harvest of soybean showed non significant differences. But the slight decreases in soil $\mathrm{pH}$ with bio-inoculants treatments were observed which may be ascribed to the secretion of organic acids by $P S B$ and Rhizobium. EC of soil was also found in the 
safe limit for the plant growth, but significant decrease was observed with application of microbial cultures as compared to initial values. Organic carbon was recorded significantly highest in treatment $\mathrm{T}_{6}(6.23 \mathrm{~g}$ $\mathrm{kg}^{-1}$ ) with inoculation of Rhizobium + Trichoderma viride over the $\mathrm{T}_{1}$ treatment and at par with remaining treatments. These results are in concurrent with the findings of Abraham and Lal (2003) who reported that the percentage of organic carbon was increased due to the integration of organic and inorganic sources of nutrients in soybean.

\section{Major nutrient availability in soil}

As per data narrated in Table 2 found that significant increase in nutrient availability in soil due to the application of microbial inoculants after harvest of crop, significantly highest value of available $\mathrm{N}\left(216 \mathrm{~kg} \mathrm{ha}^{-1}\right)$, $\mathrm{K}_{2} \mathrm{O}\left(639.3 \mathrm{~kg} \mathrm{ha}^{-1}\right)$ and $\mathrm{S}\left(12.83 \mathrm{mg} \mathrm{kg}^{-1}\right)$ was recorded in treatment $\mathrm{T}_{6}$ having $\mathrm{RDF}+$ Rhizobium + Trichoderma viride and treatment $\mathrm{T}_{4}$ was found at par with $\mathrm{T}_{6}$ treatment. This increase in available $\mathrm{N}$ might also be attributed to the greater multiplication of soil microbes which converts organically bound $\mathrm{N}$ to inorganic form as reported by Katkar et al., (2006). Further, Sheeba and Chellamuthu (1999) also reported that increase in available $\mathrm{N}$ due to the mineralization of organic matter in soil. These results are in line with the findings of Bharadwaj and Omanwar (1994), Mandal et al., (1984). Further, Pawar and Jadhav (1996) found that available $\mathrm{K}$ content was increased with integrated application of $75 \% \mathrm{RDF}$ as inorganic fertilizer with Vermicompost and $P S B$ over control, FYM at the rate of $5 \mathrm{t} \mathrm{ha}^{-1}$ and $100 \%$ RDF. It may be due to the beneficial effects of organic manures affective clay-organo interaction and direct $\mathrm{K}_{2} \mathrm{O}$ additions widening available $\mathrm{K}$ of soil. An increased availability of sulphur through chemical and microbial inoculants may be ascribed due to the accelerated microbial activities due to addition of biofertilizers as described by Pasricha and Sarkar (2002).

Table.1 Effect of various microbial cultures on chemical properties in soil after harvest of summer soybean

\begin{tabular}{|c|l|c|c|c|c|}
\hline Tr.no. & \multicolumn{1}{|c|}{ Treatment } & $\begin{array}{c}\mathbf{p H} \\
(\mathbf{1 : 2 . 5})\end{array}$ & $\left.\mathbf{E C ~} \mathbf{( d S m}^{-\mathbf{1}}\right)$ & $\mathbf{C a C O}_{\mathbf{3}}\left(\mathbf{g k g}^{-\mathbf{1}}\right)$ & $\begin{array}{c}\text { Organic } \\
\mathbf{c a r b o n} \\
\left.\mathbf{g k g}^{-1}\right)\end{array}$ \\
\hline $\mathrm{T}_{1}$ & RDF+Rhizobium & 8.25 & 0.27 & 38 & 5.25 \\
\hline $\mathrm{T}_{2}$ & $\mathrm{~T}_{1}+$ Burkholderia cepacia & 8.16 & 0.28 & 37 & 5.53 \\
\hline $\mathrm{T}_{3}$ & $\mathrm{~T}_{1}+$ Burkholderia cenocepacia & 8.14 & 0.28 & 36 & 5.80 \\
\hline $\mathrm{T}_{4}$ & $\mathrm{~T}_{1}+$ Pseudomonas fluorescens & 8.02 & 0.26 & 31 & 6.12 \\
\hline $\mathrm{T}_{5}$ & $\mathrm{~T}_{1}+$ Pseudomonas striata & 8.05 & 0.25 & 36 & 6.06 \\
\hline $\mathrm{T}_{6}$ & $\mathrm{~T}_{1}+$ Trichoderma viride & 7.96 & 0.24 & 31 & 6.23 \\
\hline $\mathrm{T}_{7}$ & $\mathrm{~T}_{1}+$ Trichoderma harzianum & 8.03 & 0.25 & 35 & 5.60 \\
\hline $\mathrm{T}_{8}$ & $\mathrm{~T}_{1}+$ Bacillus megaterium & 8.02 & 0.25 & 35 & 5.96 \\
\hline & S.E. \pm & 0.31 & 0.02 & 0.07 & 0.28 \\
\hline & C.D. at 5 \% & $\mathbf{N S}$ & $\mathbf{N S}$ & $\mathbf{N S}$ & 0.90 \\
\hline & C.V. \% & 6.69 & 14.6 & 8.3 & 2.74 \\
\hline & Initial value & 7.96 & 0.26 & 37 & 5.26 \\
\hline
\end{tabular}


Table.2 Effect of various microbial cultures on major nutrient availability in soil after harvest of soybean

\begin{tabular}{|c|l|c|c|c|c|}
\hline $\begin{array}{c}\text { Tr. } \\
\text { no. }\end{array}$ & \multicolumn{1}{|c|}{ Treatment } & $\begin{array}{c}\text { Available } \\
\mathbf{N}(\mathbf{k g} / \mathbf{h a})\end{array}$ & $\begin{array}{c}\text { Available } \\
\mathbf{P}_{\mathbf{2}} \mathbf{O}_{\mathbf{5}} \\
\mathbf{( k g} / \mathbf{h a})\end{array}$ & $\begin{array}{c}\text { Available } \\
\mathbf{K}_{\mathbf{2}} \mathbf{O}(\mathbf{k g} / \mathbf{h a})\end{array}$ & $\begin{array}{c}\text { Available } \mathbf{S} \\
(\mathbf{m g} / \mathbf{k g})\end{array}$ \\
\hline $\mathrm{T}_{1}$ & RDF+Rhizobium & 210 & 17.6 & 584.6 & 9.76 \\
\hline $\mathrm{T}_{2}$ & $\mathrm{~T}_{1}+$ Burkholderia cepacia & 200 & 19.0 & 585.0 & 10.25 \\
\hline $\mathrm{T}_{3}$ & $\begin{array}{l}\mathrm{T}_{1}+\text { Burkholderia } \\
\text { cenocepacia }\end{array}$ & 192 & 18.5 & 601.3 & 10.49 \\
\hline $\mathrm{T}_{4}$ & $\begin{array}{l}\mathrm{T}_{1}+\text { Pseudomonas } \\
\text { fluorescens }\end{array}$ & 214 & 19.8 & 630.0 & 11.77 \\
\hline $\mathrm{T}_{5}$ & $\mathrm{~T}_{1}+$ Pseudomonas striata & 196 & 21.0 & 584.0 & 10.86 \\
\hline $\mathrm{T}_{6}$ & $\mathrm{~T}_{1}+$ Trichoderma viride & 216 & 19.6 & 639.3 & 12.83 \\
\hline $\mathrm{T}_{7}$ & $\mathrm{~T}_{1}+$ Trichoderma harzianum & 183 & 19.0 & 586.3 & 11.13 \\
\hline $\mathrm{T}_{8}$ & $\mathrm{~T}_{1}+$ Bacillus megaterium & 193 & 22.4 & 573.0 & 10.72 \\
\hline & S.E.+ & 3.61 & 0.65 & 7.80 & 0.163 \\
\hline & C.D. at 5 \% & 11.05 & 2.00 & 24.03 & 0.499 \\
\hline & C.V.\% & 3.11 & 5.75 & 2.273 & 2.572 \\
\hline & Initial Value & 190 & 16.7 & 580 & 9.42 \\
\hline
\end{tabular}

Table.3 Effect of various microbial cultures on micronutrient availability in soil after harvest of soybean $\left(\mathrm{mg} \mathrm{kg}^{-1}\right)$

\begin{tabular}{|c|l|c|c|c|c|}
\hline Tr.no. & \multicolumn{1}{|c|}{ Treatment } & DTPA Zn & DTPA Fe & DTPA Mn & DTPA Cu \\
\hline $\mathrm{T}_{1}$ & RDF+Rhizobium & 0.52 & 5.24 & 7.54 & 2.35 \\
\hline $\mathrm{T}_{2}$ & $\mathrm{~T}_{1}+$ Burkholderia cepacia & 0.59 & 5.21 & 7.86 & 2.48 \\
\hline $\mathrm{T}_{3}$ & $\mathrm{~T}_{1}+$ Burkholderia cenocepacia & 0.58 & 5.23 & 8.63 & 2.50 \\
\hline $\mathrm{T}_{4}$ & $\mathrm{~T}_{1}+$ Pseudomonas fluorescens & 0.63 & 5.71 & 10.1 & 2.71 \\
\hline $\mathrm{T}_{5}$ & $\mathrm{~T}_{1}+$ Pseudomonas striata & 0.60 & 5.40 & 8.70 & 2.50 \\
\hline $\mathrm{T}_{6}$ & $\mathrm{~T}_{1}+$ Trichoderma viride & 0.66 & 5.81 & 11.2 & 2.71 \\
\hline $\mathrm{T}_{7}$ & $\mathrm{~T}_{1}+$ Trichoderma harzianum & 0.62 & 5.70 & 9.23 & 2.53 \\
\hline $\mathrm{T}_{8}$ & $\mathrm{~T}_{1}+$ Bacillus megaterium & 0.63 & 5.74 & 8.83 & 2.50 \\
\hline & S.E.土 & 0.007 & 0.079 & 0.17 & 0.03 \\
\hline & C.D. at 5 \% & 0.022 & 0.24 & 0.54 & 0.11 \\
\hline & C.V. \% & 2.063 & 2.48 & 3.40 & 2.57 \\
\hline & Initial Value & 0.56 & 5.28 & 7.22 & 2.27 \\
\hline
\end{tabular}

It may also attributed to the contribution of sulphur from single super phosphate which was used as a source of phosphorus. Similarly, Trivedi et al., (1997) were also reported that due to application of PSB there was greater mobilization of insoluble phosphorus along with enhanced transport of soil nutrients within the plant system. Also, increasing $S$ availability due to application of $\mathrm{P}$ could be due to greater root proliferation and increasing activity of sulphur solubilizing bacteria. However coming to value of $\mathrm{P}_{2} \mathrm{O}_{5}$ which was found highest in $\mathrm{T}_{8}$ treatment $\left(22.43 \mathrm{~kg} \mathrm{ha}^{-1}\right)$ with the inoculation of 
Rhizobium + Bacillus megaterium and treatment $\mathrm{T}_{5}\left(21 \mathrm{~kg} \mathrm{ha}{ }^{-1}\right)$ was at par with $\mathrm{T}_{8}$ treatment. The buildup of available $\mathrm{P}$ might be due to release of organic acid during microbial decomposition of organic matter which might help in increasing solubility of phosphates thus increased available phosphorus (Khan and Gupta, 1984). Similar results were also noted by Reddy et al., (1990).

\section{Micronutrient availability in soil}

The scrutiny of data presented in Table 3 revealed that the available micronutrients in soil after harvest of soybean crop were also influenced significantly with the inoculation of microbial cultures. DTPA $\mathrm{Zn}(0.663 \mathrm{mg}$ $\left.\mathrm{kg}^{-1}\right), \mathrm{Fe}\left(5.81 \mathrm{mg} \mathrm{kg}^{-1}\right), \mathrm{Mn}\left(11.2 \mathrm{mg} \mathrm{kg}^{-1}\right)$ and $\mathrm{Cu}\left(2.71 \mathrm{mg} \mathrm{kg}^{-1}\right)$ were noted maximum in $\mathrm{T}_{6}$ treatment receiving $\mathrm{RDF}+$ Rhizobium + Trichoderma viride. Statistically, DTPA Zn and $\mathrm{Fe}$ content in soil was found at par with $\mathrm{T}_{4}$ and $\mathrm{T}_{8}$. Solubilization of micronutrients by microbial cultures can be accomplished by range of mechanisms, which include secretion of organic acids and the release of organic acids i.e. 2-Ketogluconic and 5Ketoglyconic acids and change in the micro environment near root which increases the $\mathrm{H}^{+}$ ion concentration or protein extrusion or production of chelating agents (Altomare et al., 1999). The bacteria in soil possess surfaces that interact strongly with metal ions in soil solution (Ledin et al., 1996). Similarly, Treeby et al., (1989) also indicated that phytosiderophores are capable of increasing the amount of complexation in solution. Further, Kalinowski et al., (2000) noted that bacteria produces catecholamide siderophores that are responsible for enhanced Fe release when bacteria are present. These results are corrborate with the findings of Sharma et al., (2000); Selvi et al., (2003) and Prasad and Sinha (2000) who reported in a long term fertilizer experiment that the available $\mathrm{Zn}, \mathrm{Fe}$, $\mathrm{Cu}$ and $\mathrm{Mn}$ increased in soil when different levels of fertilizers were applied along with crop residues and organic manure.

In conclusion, on the basis of this field study it may be concluded that application of 100\% RDF along with microbial cultures such as Rhizobium + Trichoderma viride significantly improved and increases available $\mathrm{N}, \mathrm{K}_{2} \mathrm{O}, \mathrm{Zn}$ and micronutrient content in soil after harvest of soybean crop whereas, available $\mathrm{P}_{2} \mathrm{O}_{5}$ content was significantly increased with the inoculation of PSB such as Bacillus megaterium along with $100 \%$ RDF.

\section{References}

Abraham, T. and Lal, R.B. (2003). Strategies for INM technology in sustainable edapho- cultivar management for a legume based (soybean-cowpea) cropping system for the Inceptisols in NEPZ. Crop Research, Hisar26 (1): 3341.

Altomare, C., Norvel, W.A., Biorkman and Harman, G.E. (1999).Solubilization of phosphates and micronutrients by the plant growth promoting and biocontrol fungus.Trichodermaharzianum Rifai.Ap pl. Environ. Microbial.,65 (7): 2926-29.

Anonymous, (2014).Estimates of area, productivity and production of soybean in India during kharif2014. www.sopa.org/crop-po.doc

Bharadwaj, V. and Omanwar, P.K. (1994). Long-term effects of continuous rotational cropping and fertilization on crop yields and soil properties. $J$. Indian Soc. Soil. Sci.42: 387-392.

Bodkhe, A.A., Syed Ismail and JavedJani (2014). Effect of chemical fertilizers and microbial inoculants on soybean (Glycine $\max$ L.) - safflower (Carthmustinctorius)

cropping pattern. Green farming 5(3): 341-345.

Kalinowski, B.E., Liermarn, L.I., Given S.S. and Brantely, L. (2000). Rates of 
bacteria, promoted solubilization of $\mathrm{Fe}$ from minerals: A review of problems and approaches, Chemical Geology, 169: $357-370$.

Katkar R.N., Turkhede A.B and Wankhade S.T. (2006).Residual effect of organic manures and inorganic fertilizers on soil properties and seed cotton yield.PKV Res. J., 30:36-41.

Khan G. and Gupta S.K. (1984). Studies on solubilization of phosphorus in presence of different city waste. J. Indian Soc. Soil Sci.29: 123-124.

Ledin, M., Rulecker, K. and Allard, B. (1996).Zn, Cd, and $\mathrm{Hg}$ accumulation microorganisms,

organic and inorganic soil components in multi-compartment

system.Soil Biol. Biochem., 28: 791799

Mandal, B.C., Roy, Mandal, A.K. (1984). Wheat yields and soil nutrients status as influenced by continuous cropping and manuring in a Jute-rice - wheat rotation.J. Indian Soc. Soil Sci., 32: 696-700.

Pasricha, N.S. and Sarkar, A.K. (2002). Chemical of Secondary and micronutrient: In Fundamental of Soil Science. Published by Indian Soc. Soil Sci.,: 381-390.

Pawar, K.P. and A.S. Jadhav (1996). Influence of sorghum based cropping system on physio-chemicals properties of soil. J. Maharashtra Agric. Univ., 21(1):30-30.

Prasad, B and Sinha, S.K. (2000).Long-term effects of fertilizers and organic manures on crop yields, nutrient balance and soil properties in rice - wheat cropping system in Bihar. Rice -Wheat Consortium paper series 6. New Delhi, India: Rice - Wheat Consortium for the Indo-Gangetic Plains.: 105-119.

Reddy T.R, Mohan Rao, Rama, K (1990). Response of soybean (Glycine max (L.)) to nitrogen and phosphorus.Indian J. Agron., 35(3).308-310

Selvi, D., Santhy, P. and Dhakshinamoorthy, M. (2003). Efficiency of long- term integrated plant nutrient management or important soil properties of an Inceptisol. Madras. Agric. J., 90 (1012): 656-660.

Sharma, R.S, Om Prakash and Singh B.P (2000).Response of mothbean genotypes to phosphorus and row spacing under semi-and conditions. Annals of Plant and Soil Research, 2 (2) 240-243.

Sheeba, S. and Chellamuthu, S. (1999).Long term influence of organic and inorganic fertilization on macronutrient status in Inceptisols.J. Indian Soc. Soil Sci., 47 (4): 803-804.

Treeby, M., Marschoner, H. and Rheld, V. (1989).Mobilization of iron and other micronutrient cations from a calcareous soil by plant-borne, microbial and synthetic metal chelators.Pl. Soil.114: 217-226.

Trivedi, S.K., Singh, V., Shinde, C.P. and Tomar, R.A., (1997). Effect of continuous use of $\mathrm{N}, \mathrm{P}$ and $\mathrm{S}$ to Blackgram in Blackgram-mustard crop sequence.Crop Res., 13(1): 73-79.

\section{How to cite this article:}

Kranthi Kumar, B., Syed Ismail, K. Manasa and Anuradha Pawar. 2017. Enhancement of Nutrient Availability in Soil using Microbial Cultures in Soybean Grown on Vertisol. Int.J.Curr.Microbiol.App.Sci. 6(5): 2802-2807. doi: https://doi.org/10.20546/ijcmas.2017.605.315 